21. Laron Z, Pertzelan A, Karp M, Kowaldo-Silbergeld A, Daughaday WH 1971 Administration of growth hormone to patients with familial dwarfism with high immunoreactive growth hormone: measurement of sulfation factor, metabolic and linear growth responses. J Clin Endocrinol Metab 33:332-342

22. Chez RA, Hutchinson DL, Salazar H, Mintz DH 1970 Some effects of fetal and maternal hypophysectomy in pregnancy. Am J Obstet Gynecol 208:643-650

23. Hill DJ, Freemark M, Strain AJ, Handwerger S, Milner RDG 1988 Placental lactogen and growth hormone receptors in human fetal tissues: relationship to fetal plasma human placental lactogen concentrations and fetal growth. J Clin Endocrinol Metab 66:1283-1290

24. Braga S, Phillips III JA, Joss E, Schwarz H, Zuppinger K 1986 Familial growth hormone deficiency resulting from a $7.6 \mathrm{~kb}$ deletion within the growth hormone gene cluster. Am J Med Genet 25:443-452

25. Hauffa BP, Illig R, Torresani T, Stolecke H, Phillips III JA 1989 Discordant immune and growth response to pituitary and biosynthetic growth hormone in siblings with isolated growth hormone deficiency type IA. Acta Endocrinol (Copenh) 121:609-614

26. De Luca F, Duquesnoy P, Arrigo T, Lombardo F, Goossens M 1992 Very late immune response to growth hormone $(\mathrm{GH})$ therapy in an infant with $\mathrm{GH}-\mathrm{N}$ gene deletion. Acta Paediatr Scand 81:730

27. Laron Z, Kelijman M, Pertzelan A, Keret R, Shoffner JM, Parks JS 1985 Human growth hormone gene deletion without antibody formation or growth arrest during treatment: a new disease entity? Isr J Med Sci 21:999-1006

28. Andersson R 1986 Immunological aspects of human growth hormone. Acta Paediatr Scand Suppl 325:48-54

29. Nachtigal MW, Nickel BE, Cattini PA 1993 Pituitary-specific repression of placental members of the human growth hormone gene family. J Biol Chem 268:8473-8479

\title{
Announcement
}

\section{The Society for Adolescent Medicine Annual Meeting}

The Society for Adolescent Medicine, a multidisciplinary organization, will hold its annual meeting in Vancouver, British Columbia, on March 22-25, 1995, at the Vancouver Trade and Convention Center with the Waterfront Hotel as host hotel. The theme for the meeting will be "International Perspectives on Adolescent Health." In addition to addressing this topic, the meeting will present new material on a broad range of issues important to adolescent physical and emotional health, including AIDS and HIV medical management, teenage sexuality, eating disorders, depression, and risk-taking behaviors, which encompass drug and alcohol use and abuse. Meeting presentations include 3-hour clinically oriented workshops, luncheon seminars, and scientific research paper presentations and poster sessions, as well as the prestigious Gallagher Lecture Series. CME/ CEUs are available.

For further information, contact the Society for Adolescent Medicine, Suite 120, 19401 E. 40 Highway, Independence, MO 64055, (816) 795-8336. 